\title{
Retraction Note to: The impact of vegetation change and climate in coastal cities on public sports: the impact of urban heat island
}

\author{
Zhen Zeng ${ }^{1}$
}

Published online: 11 November 2021

(c) Saudi Society for Geosciences 2021

Retraction Note to: Arabian Journal of Geosciences (2021) 14: 901 https://doi.org/10.1007/s12517-021-07199-9

The Editor-in-Chief and the Publisher have retracted this article because the content of this article is nonsensical. The peer review process was not carried out in accordance with the Publisher's peer review policy. The author has not responded to correspondence regarding this retraction.

Publisher's note Springer Nature remains neutral with regard to jurisdictional claims in published maps and institutional affiliations.

The original article can be found online at https://doi.org/10.1007/ s12517-021-07199-9.

Zhen Zeng

zhenzeng2016@163.com

1 Wuhan Sports University, Wuhan 430079, China 